\title{
PENGARUH CONTRACT RELAX STRECHING TERHADAP PERUBAHAN ROM LUMBAL PADA KONDISI MEKANIKAL LOW BACK PAIN DI RSUD SALEWANGANG MAROS
}

\section{EFFECT OF CONTRACT RELAX STRECHING ON LUMBAL RANGE OF MOTION CHANGES IN MECHANICALAL LOW BACK PAIN CONDITIONS IN SALEWANGANG HOSPITAL MAROS}

\author{
Muhammad Awal, Arpandjam'an, Hasbiah, Aco Tang \\ Health Polytechnic of Makassar, Department of Physiotherapy \\ email: acotang45@gmail.com
}

\begin{abstract}
Mechanical Low Back Pain is lower back pain that occurs in normal lower back anatomical structures that are used excessively or secondary to trauma, which causes stress or strains in muscles, tendons and ligaments. This study aims to determine the effect of Contract Relax Stretching on changes in lumbar range of motion on mechanical Low Back Pain. This research is a quasi experiment with pre test - post test one group research design. This study was conducted at the Physiotherapy Clinic at Salewangang Hospital Maros, with a population of 23 patients with Low Back Pain, with samples taken based on inclusive criteria to obtain 10 Low-Pain patients with 25-55 age. The results showed that respondents aged 25-35 years were 2 people (20\%), ages 36-45 years 5 people (50\%), and ages 46-55 years were 3 people (30\%). If seen from the sex distribution, there is more female respondents, namely 6 people (60\%), and men 4 people (40\%). The results showed a change in lumbar ROM in flexion and extension disorders, with the results analyzed based on the Normality Test obtained by Shapiro-Wilk posttest flexion Sig. $p=0.858>0.05$ and posttest Extension of the Sig. $p=0.790>0.05$, which means that the flexion and extension data are normally distributed data, followed by the Paired $t$ test, the average increase in flexion is 4.920 with the sig value. $p=0,000<0,05$ and the average increase in Extension is 1,930 with the value of sig. $p=0,000<0,05$, the hypothesis is accepted which means that there is the influence of Contract Relax Stretching on Changes in Lumbar ROM in the condition of Mechanical Low Back Pain.
\end{abstract}

Keywords: Contract Relax Stretching, Lumbar Range of Motion, Mechanical Low Back Pain.

\section{ABSTRAK}

Mekanikal Low Back Pain merupakan Nyeri Pinggang Bawah yang terjadi pada struktur anatomis punggung bawah yang normal yang digunakan secara berlebihan atau akibat sekunder dari trauma, yang menimbulkan stress atau strain pada otot, tendon dan ligament. Penelitian ini bertujuan untuk mengetahui pengaruh Contract Relax Stretching terhadap Perubahan ROM Lumbal Pada Mekanikal Low Back Pain. Penelitian ini merupakan quasi eksperimen dengan desain penelitian Pre Test - Post Test One Group yang. Penelitian ini dilaksanakan di Poli Fisioterapi RSUD Salewangang Maros, dengan populasi adalah semua pasien yang mengalami Low Back Pain sebanyak 23, dengan sampel yang diambil berdasarkan kriteria inklusif sehingga diperoleh jumlah sampel penderita Mekanikal Low Back Pain sebanyak 10 orang dengan usia $25-55$. Hasil penelitian menunjukkan bahwa responden yang berusia $25-35$ tahun sebanyak 2 orang (20\%), usia 36-45 tahun 5 orang $(50 \%)$, dan usia $46-55$ tahun sebanyak 3 orang $(30 \%)$. Jika dilihat dari distribusi jenis kelamin, respoden perempuan lebih banyak yakni 6 orang (60\%), dan laki-laki 4 orang (40\%). Hasil penelitian menunjukkan adanya perubahan ROM lumbal pada gangguan Fleksi dan Ekstensi, dengan hasil yang dianalisis berdasarkan Uji Normalitas diperoleh nilai Shapiro-Wilk posttest Fleksi nilai Sig. $p=0,858>0,05$ dan posttest Ekstensi nilai Sig. $p=$ $0,790>0,05$, yang berarti data Fleksi dan Ekstensi adalah data berdistribusi normal maka dilanjutkan dengan Uji Paired t-test, diperoleh rata-rata peningkatan Fleksi sebesar 4,920 dengan nilai sig. $p=0,000<0,05$ dan rata-rata peningkatan Ekstensi sebesar 1,930 dengan nilai sig. $\mathrm{p}=0,000<0,05$ maka hipotesis diterima yang berarti ada pengaruh Contract Relax Stretching terhadap Perubahan ROM Lumbal pada kondisi Mekanikal Low Back Pain.

Kata Kunci : Contract Relax Stretching, ROM Lumbal, Mekanikal Low Back Pain.

Vol. XIII No. 2, Desember 2018

DOI: https://doi.org/10.32382/medkes.v13i2.35 


\section{PENDAHULUAN}

Setiap individu tidak terlepas dari aktivitas atau pekerjaan untuk memenuhi kebutuhan hidup. Sebagian aktivitas dan pekerjaan tersebut membutuhkan energi dan kekuatan otot yang cukup besar sehingga dapat menimbulkan berbagai macam keluhan, salah satunya adalah nyeri punggung atau Low Back Pain (LBP) (Cailiet, 2005). Nyeri punggung nonspesifik berupa ketegangan, nyeri dan / atau kekakuan di daerah punggung bawah yang tidak mungkin untuk mengidentifikasi penyebab spesifik dari rasa sakit. Beberapa struktur di belakang, termasuk sendi, diskus dan connective Tissue.

Punggung bawah umumnya didefinisikan sebagai daerah antara bagian bawah tulang rusuk dan lipatan pantat. Beberapa orang dengan nyeri punggung non-spesifik juga mungkin merasa sakit di kaki bagian atas mereka, tetapi nyeri pinggang biasanya mendominasi (Nice, 2009)

Rice (2002) dalam Shocker (2008) menyebutkan penyebab paling sering ditemukan yang dapat menyebabkan LBP adalah kekakuan dan spasme otot punggung oleh karena aktivitas tubuh yang kurang baik serta tegangnya postur tubuh. Kesalahan postural atau gerakan tubuh yang tidak proporsional dalam waktu lama dan terus menerus pada otot dan fascia akan menimbulkan nyeri kemudian terjadi spasme otot punggung. Aktifitas Fungsional yang mengalami keterbatasan adalah Fleksi dan Ekstensi Lumbal..

Pemberian Contract Relax Stretching pada kondisi mekanikal LBP bertujuan (1) Meningkatkan lingkup gerak sendi, (2) Menghilangkan spasme otot, (3) Meningkatkan panjang jaringan lunak (soft tissue), (4) Meningkatkan komplians jaringan sebagai persiapan pertandingan (Hardjono, 2012).

Masalah yang muncul akibat LBP, salah satunya adalah masalah Luas Gerak Sendi (LGS) atau Range of Movement (ROM). Pedoman Asosiasi Medis Amerika untuk mengukur derajat kecacatan didasarkan pada hilangnya ROM Lumbal, dibutuhkan angka untuk mendefinisikan cacat dengan melihat ROM sebagai tujuan dan faktor yang mudah diukur. Dalam berbagai aturan, terapi dianggap berhasil bila ROM telah dipulinkan atau setidaknya peningkatan.

Sekitar $90 \%$ dari seluruh kasus LBP disebabkan oleh faktor mekanik, yaitu LBP pada struktur anatomik normal yang digunakan secara berlebihan atau akibat sekunder dari trauma atau deformitas, yang menimbulkan stress atau strain pada otot, tendon dan ligamen. Selain itu, dari segi anatomis dan fungsional, LBP juga dapat disebabkan karena adanya kelainan pada spine, dimana spine merupakan struktur penyangga tubuh dan kepala yang selalu terlibat dalam berbagai sikap tubuh dan gerakan sehingga mudah sekali mengalami gangguan.

LBP adalah gangguan dengan banyak kemungkinan etiologi, terjadi di banyak kelompok penduduk, dan dengan banyak definisi. LBP adalah masalah yang umum, dengan prevalensi di Amerika Serikat berkisar antara $8 \%$ sampai $56 \%$. $28 \%$ pengalaman, LBP dapat melumpuhkan selama hidup, $14 \%$ mengalami episode berlangsung minimal 2 minggu, dan prevalensi seumur hidup nyeri pinggang adalah $65 \%$ sampai $80 \%$. Sebagian besar episode nyeri punggung waktunya pendek $80 \%$ sampai $90 \%$ dari serangan rendah kembali dalam waktu sekitar 6 minggu, terlepas dari jenis pengobata. Namun, beberapa studi di akhir tahun 90an menunjukkan nyeri punggung berulang atau kronis rendah, dievaluasi pada 3 bulan, 6 bulan, atau 12 bulan, mulai dari 35\% menjadi $79 \%$. Faktor risiko nyeri pinggang adalah multifaktorial, dengan banyak kemungkinan etiologi. Beberapa faktor risiko nyeri pinggang dan nyeri ekstremitas bawah meliputi faktor-faktor fisik, social karakteristik demografi, kebiasaan, dan faktor psikososial. Penyebab dan konsekuensi nyeri pinggang, pengaruh usia, jenis kelamin, karakteristik morfologi, dan genetika, dan pengaruh kerja, mekanik, sosial, kebiasaan, dan psikologis (Laxmaiah)

Hasil Observasi awal 2 bulan terakhir (Desember-Januari) di poli Fisioterapi RSUD Salewangang Maros, terdapat 671 kunjungan. 98 diantaranya mengalami Low Back Pain, 22 diantaranya mengalami mekanikal Low Back Pain. Dan secara signifikan, Contract Relax Stretching memperlihatkan perubahan luas gerak sendi dari hasil pemeriksaan sebelumnya.

\section{BAHAN DAN METODA}

\section{Lokasi Penelitian}

Penelitian ini dilakukan terhadap pasien yang berkunjung di RSUD Salewangan Maros selama 2 bulan. 


\section{Desain Penelitian}

Jenis penelitian yang digunakan dalam penelitian ini adalah penelitian Pra Experimen dengan desain penelitian Pre Test - Post Test One Group Design yang digambarkan sebagai berikut:

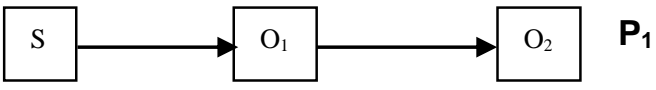

\footnotetext{
Populasi dan Sampel

$S \quad$ : Subjek

$\mathrm{P}_{1} \quad$ : Intervensi

$\mathrm{O}_{1} \quad$ : Pre Test Stretching

$\mathrm{O}_{2} \quad$ : Post Test
}

\section{Populasi dan Sampel}

Populasi dalam penelitian ini adalah semua pasien dengan kondisi Low Back Pain yang berkunjung di Rumah Sakit Salewangang Maros.

Sampel dalam penelitian adalah 10 pasien yang mengalami Mekanikal Low Back Pain dan termasuk kedalam kriteria Inklusi dan Eksklusi.

\section{Metode Pengumpulan Data}

Pengambilan sampel dilakukan dengan teknik purposive sampling dengan criteria inklusif yang ditetapkan oleh peneliti. Adapun kriteria inklusifnya adalah sebagai berikut:

1. Penderita mekanikal LBP 25-55 tahun, dan berdasarkan Assasment Fisioterapi penderita LBP tidak memiliki gejala neurologis atau gejala diskogenik

2. Bersedia menjadi responden

3. Mengalami keterbatasan Fleksi dan Ekstensi Lumbal

\section{Analisis Data}

Teknik pengolahan dan analisa data menggunakan bantuan program SPSS (Statistical Produxt For Service Solution), menggunakan Normalitas data dan analisa dengan Uji Paired t-test untuk melihat ada tidaknya pengaruh yang bermakna dalam pemberian Contract Relax Stretching pada kondisi Mekanikal Low Back Pain dengan melihat perubahan pada ROM Lumbal.

\section{HASIL}

\section{Analisis Variabel Penelitian}

Tabel 1 Menunjukkan bahwa lebih banyak responden perempuan yaitu 6 orang $(60 \%)$ daripada responden laki-laki yaitu 4 orang $(40 \%)$

Tabel 2 menunjukkan distribusi usia, diperoleh lebih banyak responden yang berusia 36 - 45 tahun yaitu 5 orang $(50 \%)$ daripada responden yang berusia $25-35$ tahun yaitu 2 orang $(20 \%)$ dan usia $46-55$ tahun yaitu 3 orang $(30 \%)$

Tabel 3 menunjukkan nilai KolmogorovSmirnov dan Shapiro-wilk. Nilai diatas menunjukkan df sebesar 10 yang berarti bahwa semua responden (10 orang) mengalami peningkatan ROM Fleksi lumbal setelah diberikan perlakuan.

Tabel 4 menunjukkan nilai KolmogorovSmirnov dan Shapiro-wilk. Nilai diatas menunjukkan df sebesar 10 yang berarti bahwa semua responden (10 orang) mengalami peningkatan ROM Ekstensi lumbal setelah diberikan perlakuan. Hal ini menunjukkan bahwa data dalam penelitian ini baik pre test maupun post test Fleksi dan Ekstensi berdistribusi normal dan dapat digunakan uji Paired sampel t-test karena data yang digunakan adalah data pre dan post test dalam 1 kelompok sampel.

Tabel 5 menunjukkan jumlah responden yang mengalami perubahan ROM berdasarkan pre test dan post test. Adanya perubahan rerata nilai dari 18,060 $\pm 1,3721 \mathrm{~cm}$ pretest Fleksi dan $14,010 \pm 0,3107 \mathrm{~cm}$ Pretest Ekstensi menjadi $22,980 \pm 0,9762 \mathrm{~cm}$ postest Fleksi dan 12,080 \pm $0,6356 \mathrm{~cm}$ postest Ekstensi. Kemudian pada post test, semua responden telah mencapai ROM Lumbal normal dengan persentase $100 \%$. Dengan demikian, pemberian Contract Relax Stretching mampu menambah ROM sebesar dengan rata-rata Fleksi $4,920 \pm 0,8135 \mathrm{~cm}$ dan Ekstensi sebesar 1,930 $\pm 0,4572 \mathrm{~cm}$.

Tabel 6 menunjukkan hasil Uji paired ttest pada ROM Fleksi Lumbal sebelum dan sesudah pemberian Contract Relax Stretching menunjukkan perbedaan yang signifikan $(\mathrm{p}=$ $0,000<0,05)$ dengan selisih rata-rata 4,920 \pm $0,8135 \mathrm{~cm}$ perbedaan nilai rerata antara pretest dan posttest. Jika dilihat dari nilai perbedaan mean (differensial mean) terjadi peningkatan rata-rata sebesar 4,92 setelah diberikan perlakuan. Perbedaan tersebut menunjukkan

Vol. XIII No. 2, Desember 2018

DOI: https://doi.org/10.32382/medkes.v13i2.35 
perbedaan yang bermakna karena hasil Uji Paired t-test diatas menunjukkan nilai t sebesar19,125 dengan sig. $p=0,000<0,05$ yang berarti bahwa ada perbedaan yang bermakna antara pre dan post terhadap peningkatan ROM Fleksi Lumbal setelah diberikan perlakuan Contract Relax Stretching.

Tabel 7 menunjukkan hasil Uji paired ttest pada ROM Ekstensi Lumbal sebelum dan sesudah pemberian Contract Relax Stretching menunjukkan perbedaan yang signifikan $(\mathrm{p}=$ $0,000<0,05)$ dengan selisih rata-rata 1,930 \pm $0,4572 \mathrm{~cm}$ perbedaan nilai rerata antara pretest dan posttest. Jika dilihat dari nilai perbedaan mean (differensial mean) terjadi peningkatan rata-rata sebesar 1,93 setelah diberikan perlakuan. Perbedaan tersebut menunjukkan perbedaan yang bermakna karena hasil Uji Paired t-test diatas menunjukkan nilai t sebesar 13,350 dengan sig. $p=0,000<0,05$, yang berarti bahwa ada perbedaan yang bermakna antara pre dan post terhadap peningkatan ROM Ekstensi Lumbal setelah diberikan perlakuan Contract Relax Stretching.

\section{PEMBAHASAN}

Sampel penelitian adalah pasien Mekanikal Low Back Pain yang berkunjung ke poli Fisioterapi RSUD Salewangan Maros yang mengalami keterbatasan Fleksi dan Ekstensi Lumbal. Responden yang menjadi sampel penelitian, dengan umur 25-55 tahun. Sampel dengan frekuensi terbanyak, yakni pada usia 3645 tahun sebanyak 5 orang (50\%). Menurut John E Murtagh (1997), nyeri pinggang umumnya terjadi pada golongan usia 16 tahun sampai dengan 80 tahun, terutama pada usia (30 tahun keatas). Hal ini dipengaruhi karena adanya penurunan struktur anatomi dan fisiologi dari sistem muskuloskeletal pada usia tersebut. Otot Erector Spine Group termasuk kedalam otot postural yang banyak mengandung serabut slow twitch, dengan karakteristik otot postural adalah mudah mengalami spasme atau tightness. Pada usia tersebut telah terjadi penurunan elastisitas dan ekstensibilitas otot sehingga adanya patologi pada vertebra Lumbal yang melibatkan otot tersebut akan menyebabkan terjadinya spasme atau tightness. Adanya taut band pada serabut otot akan menyebabkan penurunan elastisitas dan ekstensibilitas otot sehingga pada saat otot berkontraksi, taut band tersebut akan menjadi penghambat.

Vol. XIII No. 2, Desember 2018

DOI: https://doi.org/10.32382/medkes.v13i2.35
Hasil penelitian menunjukkan bahwa sampel kondisi Mekanikal Low Back Pain pada perempuan lebih banyak dibanding laki-laki. Hal ini disebabkan oleh kuantitas pekerjaan yang dilakukan oleh perempuan lebih banyak dengan menggunakan otot-otot postural seperti mencuci dan mengangkat. Dengan kemampuan fleksi dan ekstensi lumbal yang dinilai secara subjektif perempuan lebih mudah merasakan hambatan gerakan lumbal dibanding laki-laki karena lebih menghiraukan kondisi tubuhnya. Kemudian, menurut Ruth Sapsford (1999), bahwa wanita terutama ibu rumah tangga yang melakukan aktifitas pekerjaan rumah cenderung mengalami gangguan pada Lumbal daripada laki-laki karena wanita dalam melakukan aktifitas pekerjaan dirumah sering melakukan aktifitas dengan postur jelek. Umumnya wanita saat melakukan aktifitas dirumah sering melibatkan trunk saat mengangkat atau memindahkan barang dengan posisi berdiri atau duduk statis dalam waktu lama.

Untuk memastikan bahwa pemberian Contract Relax Stretching dapat meningkatkan ROM, sebelum diberikan perlakuan dilakukan pretest yaitu mengukur nilai ROM Fleksi dan ekstensi Lumbal. Kemudian setelah dilakukan perlakuan dengan pemberian Contract Relax Stretching, dilakukan post test dengan kembali mengukur ROM Fleksi dan Ekstensi Lumbal untuk melihat adanya perubahan. Berdasarkan analisis nilai ROM sebelum dan sesudah pemberian Contract Relax Stretching menujukkan adanya peningkatan ROM pada Mekanikal LBP (tabel 5)

Teknik contract relax streching dapat menghasilkan efek mekanikal yang dapat mengembalikan elastisitas otot dengan menurunnya spasme / tightness otot dan adanya efek neurofisiologi yang merangsang aktivitas mekano reseptor yang berasal dari muscle spindle dan golgi tendon organ dapat memblokir aktivitas nosiseptor sehingga lambat laun nyeri akan berkurang.

Efek dari Contract Relax Stretching dapat menghasilkan stress longitudinal pada struktur jaringan colagen yang terbentuk didalam taut band serabut otot dan merobek perlengketan yang luas serta mengembalikan elastisitas serabut otot yang terdapat taut band didalamnya. Contract Relax Stretching merupakan suatu teknik yang menggunakan kontraksi isometrik optimal dari kelompok otot agonis yang memendek dilanjutkan dengan relaksasi kemudian dilakukan stretching. 
Teknik ini melibatkan proses autogenic inhibisi dimana adanya kontraksi isometrik yang maksimal akan diikuti oleh relaksasi yang optimal. Jika ditinjau dari prinsip fisiologis Contract Relax Stretching bahwa ketika suatu otot berkontraksi sangat kuat, maka ketegangan menjadi berlebihan dan secara tiba-tiba kontraksi menjadi berhenti dan otot menjadi relaks. Relaksasi ini sebagai respon yang sangat kuat dan menyesuaikan dengan hukum kedua Sheringthon, yaitu jika otot mendapat stimulasi untuk berkontraksi maka otot antagonis menerima impuls untuk relaksasi. Jika terjadi relaksasi pada serabut otot maka otot akan lebih mudah distretching.

\section{KESIMPULAN}

Dari hasil penelitian dan pembahasan maka dapat disimpulkan sebagai berikut :

1. Dilihat dari usia menunjukkan bahwa lebih banyak responden yang berusia 36-45 tahun daripada responden yang berusia 25-35 dan 46-55 tahun, dengan frekuensi Perempuan lebih banyak dibanding laki-laki.

2. Pemberian Contract Relax Stretching dapat memberikan pengaruh yang bermakna terhadap peningkatan ROM Lumbal pada penderita Mekanikal Low Back Pain dengan rata-rata peningkatan ROM Fleksi sebesar $4,920 \mathrm{~cm}$ dan Ekstensi $1,930 \mathrm{~cm}$.

\section{SARAN}

1. Disarankan kepada masyarakat agar lebih peduli terhadap kondisi tubuh sehingga lebih mampu menghindari hambatan dan gangguan kesehatan yang mungkin terjadi dari kebiasaan sehari-hari dalam melakukan aktifitas dengan posisi yang tidak tepat.

2. Disarankan kepada Fisioterapis dilahan Praktek / Rumah sakit dan Klinik Fisioterapi, untuk menambahkan Contract Relax Stretching agar terjadi perubahan yang bermakna terhadap keterbatasan ROM Lumbal terutama yang disebabkan oleh Mekanikal Low Back Pain.

3. Disarankan kepada peneliti selanjut-nya untuk yang mengangkat masalah yang sama, agar lebih memperhatikan kualitas nyeri yang disebabkan pekerjaan responden sebagai bahan pertimbangan terhadap factor yang mempengaruhi perubahan ROM Lumbal.

\section{DAFTAR PUSTAKA}

Alemo Saeid, Sayadipour Amirali. 2008. Chronic mechanical Low Back Pain. USA: University Neurosurgical Pain Clinic.

Dagenais Simon, Haldeman Scott. 2012. Evidence-Based Management Of Low Back Pain. USA : Elsevier.

Hardjono J, Ervia Aizah. 2012. Pengaruh Penambahan Contract Relax Stretching Pada Intervensi Interferensial Current dan Ultrasound Terhadap Pengurangan Nyeri Pada Sindroma Miofasial Otot Supraspinatus. Jakarta: Universitas Esa Unggul.

Norkin Cynthia c, White D joice. 2009. Measurement of Join Motion A guide to Goniometri $4^{\text {th }}$ Edition. USA: F. A Davis Company.

Sari. __. Thesis - Perbedaan pengaruh pemberian peregangan dan mobilisasi saraf setelah pelatihan dibandingkan sebelum pelatihan terhadap gejala dan tanda DOMS otot - otot tungkai atas. Bali: Universitas Udayana. 


\section{LAMPIRAN}

Tabel 1

Distribusi Responden Berdasarkan Jenis Kelamin

\begin{tabular}{ccc}
\hline Jenis Kelamin & $\mathrm{F}$ & $\%$ \\
\hline Laki-laki & 4 & 40 \\
Perempuan & 6 & 60 \\
Jumlah & 10 & 100 \\
\hline
\end{tabular}

Tabel 2

Distribusi Responden Berdasarkan Usia

\begin{tabular}{ccc}
\hline Kelompok Usia & $F$ & $\%$ \\
\hline $25-35$ & 2 & 20 \\
$36-45$ & 5 & 50 \\
$46-55$ & 3 & 30 \\
Jumlah & 10 & $100 \%$ \\
\hline
\end{tabular}

Tabel 3

Hasil Uji Normalitas Pre dan Post test Fleksi

Tests of Normality

\begin{tabular}{lccccccr}
\hline & \multicolumn{4}{c}{ Kolmogorov-Smirnova } & \multicolumn{3}{c}{ Shapiro-Wilk } \\
\hline & Statistic & df & Sig. & Statistic & & df & \multicolumn{2}{c}{ Sig. } \\
\hline Pretest_Fleksi & .153 & 10 & $.200^{*}$ & & .952 & 10 & .687 \\
Posttest_Fleksi & .142 & 10 & $.200^{*}$ & & .967 & 10 & .858 \\
\hline
\end{tabular}

a. Lilliefors Significance Correction

Tabel 4

Hasil Uji Normalitas Pre dan Post test Ekstensi

Tests of Normality

\begin{tabular}{lccccccc}
\hline & \multicolumn{3}{c}{ Kolmogorov-Smirnova } & \multicolumn{3}{c}{ Shapiro-Wilk } \\
& Statistic & Df & Sig. & Statistic & df & Sig. \\
\hline Pretest_Ekstensi & .213 & 10 & $.200^{*}$ & .945 & 10 & .605 \\
Posttest_Ekstensi & .150 & 10 & $.200^{*}$ & .960 & 10 & .790 \\
\hline
\end{tabular}

a. Lilliefors Significance Correction

${ }^{*}$. This is a lower bound of the true significance. 
Tabel 5

Distribusi nilai ROM Lumbal Pre test dan Post test

\begin{tabular}{ccccccc}
\hline \multirow{2}{*}{ Responden } & \multicolumn{3}{c}{ ROM Lumbal } & \multicolumn{2}{c}{ Peningkatan ROM } \\
\cline { 2 - 5 } & \multicolumn{2}{c}{ Pre Test } & \multicolumn{2}{c}{ Post Test } & & \\
\cline { 2 - 5 } & Fleksi & Extensi & Fleksi & Ekstensi & Fleksi & Ekstensi \\
\hline 1 & 19 & 13,6 & 22,8 & 12 & 3,8 & 1,6 \\
2 & 17 & 13,9 & 22,5 & 12,2 & 5,5 & 1,7 \\
3 & 19,2 & 13,7 & 24,6 & 11 & 5,4 & 2,7 \\
4 & 16,2 & 14,6 & 21,6 & 13 & 5,4 & 1,6 \\
5 & 18 & 14,4 & 22 & 12,8 & 4 & 1,6 \\
6 & 19,4 & 13,8 & 23,8 & 11,8 & 4,4 & 2 \\
7 & 17,5 & 14 & 23,3 & 12,3 & 5,8 & 1,7 \\
8 & 16 & 14,2 & 22 & 12 & 6 & 2,2 \\
9 & 18,3 & 14 & 23,2 & 12,5 & 4,9 & 1,5 \\
10 & 20 & 13,9 & 24 & 11,2 & 4 & 2,7 \\
\hline Mean / Rerata & 18,060 & 14,010 & 22,980 & 12,080 & 4,920 & 1,930 \\
Standar Deviasi & 1,3721 & 0,3107 & 0,9762 & 0,6356 & 0,8135 & 0,4572 \\
\hline
\end{tabular}

Tabel 6

Hasil Uji Paired t-test ROM Pretest dan Posttest Fleksi

\begin{tabular}{lcccccc}
\hline $\begin{array}{c}\text { Kelompok } \\
\text { sampel }\end{array}$ & $\mathrm{N}$ & Mean & $\mathrm{SD}$ & $\begin{array}{c}\text { Difference } \\
\text { Mean }\end{array}$ & $\mathrm{t}$ & Sig. \\
\hline Pre test & 10 & 18,060 & 1,3721 & & & \\
Post test & 10 & 22,980 & 0,9762 & $-4,9200$ & -19.125 & 0,000 \\
Selisih & 10 & 4,920 & 0,8135 & & & \\
\hline
\end{tabular}

Tabel 7

Hasil Uji Paired t-test ROM Pretest dan Posttest Ekstensi

\begin{tabular}{lcccccc}
\hline $\begin{array}{c}\text { Kelompok } \\
\text { Sampel }\end{array}$ & $\mathrm{N}$ & Mean & $\mathrm{SD}$ & $\begin{array}{c}\text { Difference } \\
\text { Mean }\end{array}$ & $\mathrm{t}$ & Sig. \\
\hline Pre test & 10 & 14,010 & 0,3107 & & & \\
Post test & 10 & $\begin{array}{c}12,080 \\
1,930\end{array}$ & 0,6356 & 1,9300 & 13,350 & 0,000 \\
Selisih & 10 & 0,4572 & & & \\
\hline
\end{tabular}

